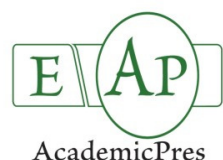

AcademicPres

\title{
Sensory Quality of 'Cherry' Tomatoes in Relation to 1-MCP Treatment and Storage Duration
}

\author{
Marek GAJEWSKI*, Katarzyna MAZUR, Jadwiga RADZANOWSKA, Katarzyna \\ KOWALCZYK, Monika MARCINKOWSKA, Klaudyna RYL, Karolina KALOTA
}

Warsaw University of Life Sciences - SGGW, Department of Vegetable and Medicinal Plants, Nowoursynowska 166, 02-787 Warszawa, Poland; marek_gajewski@sggw.pl (*correspondingauthor)

\begin{abstract}
1-MCP (1-methylcyclopropene), the ethylene receptors blocker, is used in horticultural practice for prolonging 'shelf-life' of several species of fruits and vegetables. The objective of this study was to determine the effect of 1-MCP treatment on sensory characteristics of 'cherry' type tomatoes (Solanum lycopersicum L. var. cerasiforme) after 4-week storage. In the experiment the fruits were harvested at pink and light-red fruit stages (3rd and 5th stage, according to USDA classification), and stored for 3 and 4 weeks at $12{ }^{\circ} \mathrm{C}$, then moved to $20^{\circ} \mathrm{C}$ for 2 days to obtain marketable maturity. 1 -MCP was applied after harvest in concentration of 1 ppm, for 12 hours at $18^{\circ} \mathrm{C}$. The plants belonging to the 'Dasher $F_{1}$ ' cultivar were grown in a greenhouse in rockwool slabs and fruits were harvested in June. Sensory analysis was performed in expert panel with Quantitative Descriptive Analysis (QDA), using 12 sensory descriptors concerning smell, taste, flavour and texture of the fruits. Also semi-consumer test of liking was carried out. As the control freshly harvested red fruits at optimal consumer's maturity were used. The 1-MCP treated fruits harvested in the lightred stage were of better sensory quality than the untreated ones, similar to freshly harvested, but in the case of the pink fruits, the quality was rated lower. It can be concluded that 1-MCP treatment was effective in delaying ripening of the fruits by better keeping their firmness and colour, however in the case of fruits harvested in earlier stage, overall sensory quality and consumer acceptance was scored lower than for the freshly harvested ones, mainly due to more intensive sour taste and lower sweetness.
\end{abstract}

Keywords: tomato fruit, Solanum lycopersicum, sensory attributes, quantitative descriptive analysis, consumer test

\section{Introduction}

Tomato, one of the most popular vegetables worldwide, is consumed for its sensory value, attractive appearance and nutritional value. Recently, 'cherry' type tomatoes, with small fruits became popular in Europe. Tomato is a climacteric fruit and its ripening process can be accelerated by ethylene. There are reports pointing out potential benefits of 1-MCP (1-methylcyclopropene) in postharvest of fruits and vegetables resulting in delaying their ripening or senescence processes. 1-MCP was introduced to horticultural practice in 1999 in the USA. For vegetables and fruits it is used as the formulation known as SmartFresh ${ }^{\mathrm{TM}}$. 1-MCP is safe for human, quickly diffuses from the plant tissue after the treatment (Blankenship and Dole, 2003; Watkins, 2006). It is believed that mechanism of 1-MCP action lays in blocking ethylene receptors in plant cells. It results in delaying fruits and vegetables ripening or senescence and therefore extends their storage ability (Fan and Mattheis, 2000; Wills and $\mathrm{Ku}, 2002$; Watkins, 2006). The effect depends on 1-MCP concentration and time of the treatment. It was reported that 1-MCP reduced production of ethylene, cell respiration, restrained fruit colour changes, softening, taste and aroma degradation as well as diseases of fruits (Moretti et al., 2002; Wills and $\mathrm{Ku}, 2002$; Mostofi et al., 2003). There are reports that $1-\mathrm{MCP}$ treatment markedly affects also ripening of tomato fruits by inhibiting ethylene production (Opiyo and Ying, 2005; Beno-Moualem et al., 2004; Tassoni et al., 2006; Watkins, 2006; Tadesse et al., 2012), significantly reduces respiration rates in the fruits (Guillén et al., 2007), delays change of fruits colour and reduces softening and decay of stored fruits (Guillén et al., 2006). Between 1-MCP treated and untreated ripe tomato fruits no differences in titratable acidity, soluble solids, fructose and glucose contents were reported (Opiyo and Ying, 2005; Ergun et al., 2006; Guillén et al., 2006). Some authors pointed out possibilities of use of the treatment for prolonging shelf life of tomatoes. According to Mir et al. (2004) one treatment with 1-MCP prolonged ripening of both breaker and pink tomato fruits for 4 to 6 days and delayed loss of firmness of the fruits. Vijay et al. (2010) reported that the treatment is effective even for tomato fruits stored at high temperatures $\left(25-30{ }^{\circ} \mathrm{C}\right)$. According to Huber (2008) 1-MCP treatment of tomatoes should be done when the fruits start to ripe, what results in their better quality. However, literature data on the effectiveness of 1-MCP treatment of tomato fruits in different ripening 
stages are insufficient, especially as regards 'cherry' type tomatoes.

Tomato fruits are chilling sensitive, so the optimum temperature for storage of tomato fruits harvested at the mature green or breaker stage of maturity is $12.5-13{ }^{\circ} \mathrm{C}$ (Roberts et al., 2002; Getinet et al., 2008; Suslow and Cantwell, 2009). In the experiments of Gajewski (2000), tomatoes harvested at the breaker stage of maturity kept well their quality for 4 weeks at the temperature of 12-13 ${ }^{\circ} \mathrm{C}$. Due to low storage ability of tomato fruits, various methods of prolonging storage period for the fruits are investigated, including controlled atmosphere storage and heat treatment (Sayed et al., 2004; Toor and Savage, 2006).

Sensory characteristics of tomato fruit is a very important component of its quality and decides on a high degree on consumer's acceptance of the fruit (Azodanlou et al., 2003). For the unification of sensory methods ISO standards were approved (Anonymous, 1996, 1999). There are some reports on relationship between sensory quality and physical or chemical characteristics of different fruits (Gajewski and Arasimowicz, 2004), but just a few reports concerning sensory characteristics of 'cherry' tomatoes. However, some authors indicate that negative influence of 1-MCP treatment on sensory characteristics of tomatoes is possible (Cliff et al., 2009). It is not clear if it affects consumer acceptance of the fruit. Tomatoes of 'cherry' type are a perishable crop, so method of prolonging their shelf life would be suitable for practice.

The objective of this study was to determine the effect of 1-MCP treatment on sensory quality traits of 'cherry' tomatoes (Solanum lycopersicum L. var. cerasiforme). The results of the study could explain in what degree this method of postharvest treatment positively or adversely affects sensory quality of the fruits and their consumer acceptance.

\section{Materials and methods}

The work was carried out at Warsaw University of Life Sciences. The cultivar used in the study was 'Dasher $\mathrm{F}_{1}$ '. This cultivar is a standard 'cherry' type one and is characterized by small (15-17 g weight) red fruits, which are slightly elongated in shape. The fruits were obtained from tomato plants grown in the experimental greenhouse with controlled climate conditions (temperature and humidity). Standard coconut slabs were used as the growing medium in the greenhouse. Tomato seeds were sown at the beginning of January, then the seedlings were transplanted to the final place of cultivation in February, at the density of 2.7 plants per $\mathrm{m}^{2}$. Drop irrigation system was applied in the greenhouse for watering and fertilizing the plants. Nutrients concentrations $\left(\mathrm{mg} \cdot \mathrm{dm}^{-3}\right)$ in the feeding solution were kept on optimal level for tomato plants, and were as follows: $\mathrm{N}$ $\mathrm{NO}_{3}-210, \mathrm{P}-60, \mathrm{~K}-340, \mathrm{Mg}-50, \mathrm{Ca}-200, \mathrm{Fe}-2.0$, $\mathrm{Mn}-0.6, \mathrm{~B}-0.3, \mathrm{Cu}-0.15, \mathrm{Zn}-0.3, \mathrm{Mo}-0.05$.

The fruits for the experiment were harvested at pink fruit and light-red fruit stages (3rd and 5th maturity stages, according to USDA classification), selected in respect of uniformity, and stored for 3 and 4 weeks at experimental cold store, at the temperature of $12{ }^{\circ} \mathrm{C}$ and $85 \% \mathrm{RH}$, than moved for 2 days to $20^{\circ} \mathrm{C}$ to obtain marketable maturity. 1 MCP was applied in the form of SmartFresh ${ }^{\mathrm{TM}}$ (Agrofresh
Inc.) formulation directly after harvest, in special air-tight steel chambers (capacity of $1 \mathrm{~m}^{3}$ ) in concentration of 1 $\mu \mathrm{L} \cdot \mathrm{L}^{-1}$, for 12 hours at $18{ }^{\circ} \mathrm{C}$. The conditions of the treatment were chosen according to previous own experiments and literature data (Wills and $\mathrm{Ku}, 2002$; Watkins, 2006). As the control in sensory evaluation of stored fruits harvested in both stages of maturity freshly harvested fruits, at optimal consumer's maturity (i.e. red, ripe fruits) were used.

Sensory analysis was carried out in sensory laboratory of the Department, equipped according to ISO standard (Anonymous, 1999). The established expert panel, consisting of 12 persons, previously selected and trained according to ISO standard (Anonymous, 1996), carried out the evaluation using Quantitative Descriptive Analysis (QDA) method. At the first part of the QDA procedure 'brainstorming' sessions were run to determine sensory attributes for the tomatoes. Panelists received samples of 'cherry' tomatoes, varying in sensory properties, and generated a set of 12 descriptors (Tab. 1) for odour, appearance, texture and flavour/taste of the fruits. Also, overall quality impression was taken into account as a separate descriptor.

Tab. 1. Quality descriptors used in the quantitative descriptive analysis of 'cherry' tomatoes

\begin{tabular}{|c|c|c|c|}
\hline No. & Descriptors & Definition & Anchoring points \\
\hline 1 & 'tomato' odour & $\begin{array}{l}\text { characteristic odour } \\
\text { of tomato }\end{array}$ & $\begin{array}{c}\text { low intensity - high } \\
\text { intensity }\end{array}$ \\
\hline 2 & foreign odour & $\begin{array}{l}\text { unusual odour for } \\
\text { tomato fruit }\end{array}$ & $\begin{array}{c}\text { low intensity - very } \\
\text { intensity }\end{array}$ \\
\hline 3 & $\begin{array}{l}\text { flesh colour } \\
\text { intensity }\end{array}$ & $\begin{array}{l}\text { red colour intensity } \\
\text { for half-cut fruit }\end{array}$ & pale red - dark red \\
\hline 4 & skin thickness & $\begin{array}{l}\text { impression during } \\
\text { chewing the fruit }\end{array}$ & thin skin - thick skin \\
\hline 5 & flesh firmness & $\begin{array}{l}\text { impression during } \\
\text { chewing the fruit }\end{array}$ & soft fruit - firm fruit \\
\hline 6 & flesh mealiness & $\begin{array}{l}\text { impression during } \\
\text { chewing the fruit }\end{array}$ & low - high mealiness \\
\hline 7 & flesh juiciness & $\begin{array}{l}\text { impression during } \\
\text { chewing the fruit }\end{array}$ & not juicy - very juicy \\
\hline 8 & 'tomato' flavour & $\begin{array}{l}\text { characteristic } \\
\text { flavour for tomato }\end{array}$ & $\begin{array}{c}\text { low intensity - high } \\
\text { intensity }\end{array}$ \\
\hline 9 & sour taste & basic taste & $\begin{array}{c}\text { low intensity - high } \\
\text { intensity }\end{array}$ \\
\hline 10 & sweet taste & basic taste & $\begin{array}{c}\text { low intensity - high } \\
\text { intensity }\end{array}$ \\
\hline 11 & bitter taste & basic taste & none - very intensive \\
\hline 12 & foreign taste & $\begin{array}{l}\text { unusual taste for } \\
\text { tomato fruit }\end{array}$ & none - very intensive \\
\hline 13 & Overall quality & $\begin{array}{l}\text { general sensory } \\
\text { quality impression }\end{array}$ & $\begin{array}{c}\text { low quality - high } \\
\text { quality }\end{array}$ \\
\hline
\end{tabular}

The main analysis was performed in separate booths, equipped with computers. Every assessor received samples of the tomatoes. The sample replicates were served in coded small plastic containers, covered by lids, in a totally random order. The assessments were marked on the monitors on non-structural lines with anchoring points (described in Tab. 1). Results were converted to numerical values (from 0 to 10 points). The analysis was performed during two independent sessions for each of maturity stage. For coding samples and for initial processing of the data, Analsens 
32

software was used. Semi-consumer test of 'cherry' tomatoes liking was also performed alongside with QDA procedure. For this evaluation non-structural scale was also used, with anchoring points: 'I do not like it' - 'I like it very much'.

For the analysis of variance Anova was applied (StatgraphicsPlus 4.1 ${ }^{\mathrm{TM}}$ software) and Tukey's HSD test was used to determine which values differ significantly at $\alpha \leq 0.05$. Correlation coefficients between scores for overall quality impression or for consumer liking and for several sensory quality descriptors were also calculated. For the calculation all single scores of assessors were taken into account and significance levels were determined. S

\section{Results and discussion}

Storage conditions concerning temperature and relative humidity used in the study for the tomato fruits were in accordance with recommendations (Saltweit, 1997) for not fully ripen tomatoes, and enabled slow ripening of the fruits during the storage. The QDA (Quantitative Descriptive Analysis) method used in the study is often applied for detailed description of sensory characteristics of food products. In this method an assumption is done that sensory quality is a complex of many descriptors (attributes), which can be individually estimated by a consumer (Meilgaard et al., 1999). In the analysis 12 sensory quality attributes were used, and, additionally, overall sensory quality impression was also scored. The set of sensory attributes elaborated by the panelists related to all aspects of sensory quality of tomatoes. The attributes are given in Tables 2-5 and devided on those concerning odour, mechanical properties (texture), colour and taste/flavour. Scores for the attributes are given in the tables for both storage periods separately (i.e. for 3 and 4 weeks). It should be noted that control fruits (freshly harvested fruits in red maturity stage) were used as a 'standard' in each of the experts sessions and since the fruits could vary in quality, the scores for control samples used for pink or light-red stored fruits evaluation might vary. The discussion of results obtained in the study is restricted, since there is shortage of data in literature on the influence of 1-MCP on sensory characteristics of 'cherry' tomatoes.

Tab. 2. Scores for sensory attributes concerning odour, colour and texture for 'cherry' tomato fruits after 3-week storage (scale 0-10)

\begin{tabular}{|c|c|c|c|c|c|c|c|c|}
\hline \multirow{2}{*}{$\begin{array}{c}\text { Maturity } \\
\text { stage at } \\
\text { harvest }\end{array}$} & \multirow[b]{2}{*}{ Treatment } & \multicolumn{7}{|c|}{ Sensory attributes } \\
\hline & & $\begin{array}{l}\text { 'Tomato' } \\
\text { odour }\end{array}$ & $\begin{array}{c}\text { Foreign } \\
\text { odour }\end{array}$ & $\begin{array}{l}\text { Flesh } \\
\text { colour }\end{array}$ & $\begin{array}{c}\text { Skin } \\
\text { thickness }\end{array}$ & $\begin{array}{c}\text { Flesh } \\
\text { firmness }\end{array}$ & $\begin{array}{c}\text { Flesh } \\
\text { mealiness }\end{array}$ & $\begin{array}{c}\text { Flesh } \\
\text { juiciness }\end{array}$ \\
\hline \multirow{4}{*}{ Light-red } & Control fruit & $6.83 \mathrm{~d}$ & $0.04 \mathrm{a}$ & $6.18 \mathrm{c}$ & $5.52 \mathrm{a}$ & $3.79 \mathrm{a}$ & $1.19 \mathrm{a}$ & $7.69 c$ \\
\hline & Untreated & $6.33 c$ & $0.00 \mathrm{a}$ & $6.79 \mathrm{~d}$ & $5.75 a$ & $4.81 \mathrm{ab}$ & $1.29 \mathrm{a}$ & $7.28 \mathrm{bc}$ \\
\hline & 1-MCP treated & $6.18 c$ & $0.19 \mathrm{a}$ & $5.40 \mathrm{~b}$ & $5.94 \mathrm{ab}$ & $5.05 \mathrm{ab}$ & $1.45 \mathrm{a}$ & $7.16 \mathrm{~b}$ \\
\hline & Means & $6.45 \mathrm{~B}$ & $0.08 \mathrm{~A}$ & $6.12 \mathrm{~A}$ & $5.74 \mathrm{~A}$ & $4.55 \mathrm{~A}$ & $1.31 \mathrm{~A}$ & $7.38 \mathrm{~A}$ \\
\hline \multirow{4}{*}{ Pink } & Control fruit & $5.69 \mathrm{~b}$ & $0.25 \mathrm{a}$ & $7.11 \mathrm{~d}$ & $5.07 \mathrm{a}$ & $3.29 \mathrm{a}$ & $1.36 \mathrm{a}$ & $7.41 \mathrm{bc}$ \\
\hline & Untreated & $5.41 \mathrm{a}$ & $0.32 \mathrm{a}$ & $6.17 c$ & $6.07 \mathrm{ab}$ & $4.36 \mathrm{ab}$ & $1.60 \mathrm{a}$ & $7.02 \mathrm{~b}$ \\
\hline & 1-MCP treated & $5.48 \mathrm{a}$ & $0.05 \mathrm{a}$ & $4.21 \mathrm{a}$ & $6.64 b$ & $5.78 \mathrm{~b}$ & $1.18 \mathrm{a}$ & $6.17 \mathrm{a}$ \\
\hline & Means & $5.53 \mathrm{~A}$ & $0.21 \mathrm{~A}$ & $5.83 \mathrm{~A}$ & $5.93 \mathrm{~A}$ & $4.48 \mathrm{~A}$ & $1.38 \mathrm{~A}$ & $6.87 \mathrm{~A}$ \\
\hline
\end{tabular}

Note to Tab. 2-6: different letters in each column are used for marking significant differences at $\alpha \leq 0.05$; small letters - between objects, capitals - between means of maturity stages

The results of sensory analysis for attributes concerning odour, colour and mechanical properties of tomato fruits are shown in Tab. 2 and Tab. 3. After 3 weeks of storage the fruits harvested in pink fruit stage were characterized by a lower intensity of typical 'tomato' aroma compared to the fruits harvested in the red stage (Tab. 2).

The influence of 1-MCP treatment on this quality attribute was insignificant for both maturity stages compared to stored untreated fruits. However, freshly harvested red fruits (control) showed a higher intensity of the tomato odour. With extending storage period up to 4 weeks, the differences between treated and untreated fruits remained insignificant (with a tendency to a higher 'tomato' odour intensity for 1-MCP treated fruits), but the difference between stored and freshly harvested control fruits increased (Tab. 3).

Foreign odour (untypical odour of tomato fruit) was detected at a very low level in all fruit samples, independent on maturity stage, but increased a little after 4 weeks of storage. There were found significant differences between experimental objects in the case of flesh colour. For the fruits stored for 3 and 4 weeks the paler red colour was detected in 1-MCP treated samples than in untreated ones or in the control. No significant differences between maturity stages as regards skin thickness attribute were found. The thickest skin was detected in 1-MCP treated pink fruits, both after 3 and 4 weeks of storage. In the case of flesh firmness a tendency to higher firmness for 1-MCP treated stored fruits compared to the untreated ones was found, and for the fruits stored for 4 weeks their firmness was rated significantly lower than for the freshly harvested ones.

This finding is in accordance with reports of Moretti et al. (2002), Wills and $\mathrm{Ku}$ (2002) and Mostofi et al. (2003) pointing out that $1-\mathrm{MCP}$ treatment delays tomato fruit ripening, including their softening. With extending storage period from 3 to 4 weeks flesh firmness showed a tendency to decrease, which indicated that ripening process in 1MCP treated fruits was still going slowly.

As regards flesh mealiness, no significant differences were found for experimental objects, both after 3 and 4 weeks of storage. This attribute was rated on a very low level, for the fruits stored for 4 weeks, especially. Flesh juiciness was rated as the highest for control of both lightred and pink fruits evaluated after 3 weeks of storage, but after 4 weeks significant differences were detected between untreated pink fruits and other objects (except the control for the pink fruits). 
Tab. 3. Scores for sensory attributes concerning odour, colour and texture for 'cherry' tomato fruits after 4-week storage (scale 0-10)

\begin{tabular}{|c|c|c|c|c|c|c|c|c|}
\hline \multirow{2}{*}{$\begin{array}{c}\text { Maturity } \\
\text { stage at } \\
\text { harvest }\end{array}$} & \multirow[b]{2}{*}{ Treatment } & \multicolumn{7}{|c|}{ Sensory attributes } \\
\hline & & $\begin{array}{c}\text { 'Tomato' } \\
\text { odour }\end{array}$ & $\begin{array}{c}\text { Foreign } \\
\text { odour }\end{array}$ & $\begin{array}{l}\text { Flesh } \\
\text { colour }\end{array}$ & $\begin{array}{c}\text { Skin } \\
\text { thickness }\end{array}$ & $\begin{array}{c}\text { Flesh } \\
\text { firmness }\end{array}$ & $\begin{array}{c}\begin{array}{c}\text { Flesh } \\
\text { mealiness }\end{array} \\
\end{array}$ & $\begin{array}{c}\text { Flesh } \\
\text { juiciness }\end{array}$ \\
\hline \multirow{4}{*}{ Light-red } & Control fruit & $4.95 \mathrm{a}$ & $0.43 \mathrm{ab}$ & $4.28 \mathrm{a}$ & $6.40 \mathrm{a}$ & $3.84 \mathrm{c}$ & $0.91 \mathrm{a}$ & $6.47 \mathrm{~b}$ \\
\hline & Untreated & $5.29 \mathrm{ab}$ & $0.83 \mathrm{~b}$ & $5.45 b$ & $6.45 \mathrm{a}$ & $2.25 \mathrm{a}$ & $0.50 \mathrm{a}$ & $6.49 \mathrm{~b}$ \\
\hline & 1-MCP treated & $5.49 \mathrm{~b}$ & $0.70 \mathrm{~b}$ & $4.77 \mathrm{a}$ & $6.74 \mathrm{ab}$ & $2.87 \mathrm{~b}$ & $0.35 \mathrm{a}$ & $6.55 \mathrm{~b}$ \\
\hline & Means & $5.24 \mathrm{~A}$ & $0.65 \mathrm{~A}$ & $4.83 \mathrm{~A}$ & $6.53 \mathrm{~A}$ & $3.99 \mathrm{~A}$ & $0.59 \mathrm{~A}$ & $6.50 \mathrm{~A}$ \\
\hline \multirow{4}{*}{ Pink } & Control fruit & $5.43 \mathrm{~b}$ & $0.02 \mathrm{a}$ & $5.04 \mathrm{ab}$ & $6.24 \mathrm{a}$ & $3.29 b c$ & $0.99 \mathrm{a}$ & $6.28 \mathrm{ab}$ \\
\hline & Untreated & $4.96 \mathrm{a}$ & $1.08 \mathrm{~b}$ & $5.45 b$ & $7.27 \mathrm{~b}$ & $2.73 \mathrm{~b}$ & $1.20 \mathrm{a}$ & $5.96 \mathrm{a}$ \\
\hline & 1-MCP treated & $5.19 \mathrm{ab}$ & $0.88 \mathrm{~b}$ & $4.29 a$ & $7.41 \mathrm{~b}$ & $2.98 \mathrm{~b}$ & $0.60 \mathrm{a}$ & $6.59 \mathrm{~b}$ \\
\hline & Means & $5.19 \mathrm{~A}$ & $0.66 \mathrm{~A}$ & $4.93 \mathrm{~A}$ & $6.97 \mathrm{~A}$ & $3.00 \mathrm{~A}$ & $0.93 \mathrm{~A}$ & $6.28 \mathrm{~A}$ \\
\hline
\end{tabular}

Results of sensory analysis concerning attributes of the highest for control fruits. It is not a surprise because flavour/taste are presented in Tab. 4 and Tab. 5. It can be seen that intensity of this characteristic flavour for tomato was rated as the highest for control in evaluations performed both after 3 and 4 weeks of storage, but the differences between objects were not always statistically significant. The intensity of this flavour showed a tendency to decrease with increasing time of storage. Fruits harvested in pink stage of maturity were characterized by a lower tomato flavour intensity after storage than fruits harvested in later, light-red stage. It should be noted that sour taste, when present in a high intensity, is an undesirable trait in tomato fruits and usually also in most other foods. In the study it was found that 1-MCP treated fruits were characterized by slightly higher sour taste than the untreated fruits, both after 3 and 4 weeks of storage. The control fruits showed the lowest intensity of this taste. By contrast, sweet taste intensity was these fruits ripened on the plant to obtain full maturity and they could accumulate more assimilates. As regards the effect of 1-MCP treatment, a tendency was found (not significant for 3 weeks of storage) to lower sweet taste intensity for the 1-MCP treated fruits than for the untreated ones. As we previously reported (Mazur et al., 2013), 1-MCP treated 'cherry' tomatoes showed significantly higher titratable acidity and a little lower sugars content after two-week storage, so results of this sensory evaluation probably reflects the phenomenon. There were found no differences in bitter taste intensity between the objects, including the control fruits, which is a positive finding since this taste is an undesirable one in most foods. The same can be said as regards foreign taste, which was detected by the panelists on a very low level in all fruit samples.

Tab. 4. Scores for sensory attributes concerning flavour/taste and overall quality for 'cherry' tomato fruits after 3-week storage (scale 0-10)

\begin{tabular}{|c|c|c|c|c|c|c|c|}
\hline \multirow{2}{*}{$\begin{array}{c}\text { Maturity } \\
\text { stage at } \\
\text { harvest }\end{array}$} & \multirow[b]{2}{*}{ Treatment } & \multicolumn{6}{|c|}{ Sensory attributes } \\
\hline & & $\begin{array}{l}\text { 'Tomato' } \\
\text { flavour }\end{array}$ & $\begin{array}{l}\text { Sour } \\
\text { taste }\end{array}$ & $\begin{array}{c}\text { Sweet } \\
\text { taste }\end{array}$ & $\begin{array}{c}\text { Bitter } \\
\text { taste }\end{array}$ & $\begin{array}{c}\text { Foreign } \\
\text { taste }\end{array}$ & $\begin{array}{l}\text { Overall } \\
\text { quality }\end{array}$ \\
\hline \multirow{4}{*}{ Light-red } & Control fruit & $6.97 \mathrm{~b}$ & $3.37 \mathrm{a}$ & $5.57 \mathrm{c}$ & $0.15 \mathrm{a}$ & $0.00 \mathrm{a}$ & $7.73 \mathrm{c}$ \\
\hline & Untreated & $6.67 \mathrm{ab}$ & $3.33 \mathrm{a}$ & $5.08 c$ & $0.33 \mathrm{a}$ & $0.00 \mathrm{a}$ & $7.35 \mathrm{bc}$ \\
\hline & 1-MCP treated & $6.22 \mathrm{ab}$ & $4.77 \mathrm{~b}$ & $4.06 \mathrm{~b}$ & $0.29 \mathrm{a}$ & $0.00 \mathrm{a}$ & $7.70 \mathrm{c}$ \\
\hline & Means & $6.62 \mathrm{~A}$ & $3.82 \mathrm{~A}$ & $4.90 \mathrm{~A}$ & $0.26 \mathrm{~A}$ & $0.00 \mathrm{~A}$ & $7.59 \mathrm{~B}$ \\
\hline \multirow{4}{*}{ Pink } & Control fruit & $6.90 \mathrm{~b}$ & $3.15 \mathrm{a}$ & $5.39 \mathrm{c}$ & $0.12 \mathrm{a}$ & $0.00 \mathrm{a}$ & $7.05 \mathrm{~b}$ \\
\hline & Untreated & $6.23 \mathrm{ab}$ & $4.18 \mathrm{ab}$ & $3.70 \mathrm{~b}$ & $0.14 \mathrm{a}$ & $0.03 \mathrm{a}$ & $6.99 \mathrm{ab}$ \\
\hline & 1-MCP treated & $5.92 \mathrm{a}$ & $5.44 \mathrm{c}$ & $2.87 \mathrm{a}$ & $0.08 \mathrm{a}$ & $0.07 \mathrm{a}$ & $6.40 \mathrm{a}$ \\
\hline & Means & $6.35 \mathrm{~A}$ & $4.26 \mathrm{~A}$ & $3.99 \mathrm{~A}$ & $0.11 \mathrm{~A}$ & $0.03 \mathrm{~A}$ & $6.81 \mathrm{~A}$ \\
\hline
\end{tabular}

Tab. 5. Scores for sensory attributes concerning flavour/taste and overall quality for 'cherry' tomato fruits after 4-week storage (scale 0-10)

\begin{tabular}{|c|c|c|c|c|c|c|c|}
\hline \multirow{2}{*}{$\begin{array}{c}\text { Maturity } \\
\text { stage at } \\
\text { harvest }\end{array}$} & \multirow[b]{2}{*}{ Treatment } & \multicolumn{6}{|c|}{ Sensory attributes } \\
\hline & & $\begin{array}{l}\text { 'Tomato' } \\
\text { flavour }\end{array}$ & $\begin{array}{l}\text { Sour } \\
\text { taste }\end{array}$ & $\begin{array}{c}\text { Sweet } \\
\text { taste }\end{array}$ & $\begin{array}{c}\text { Bitter } \\
\text { taste }\end{array}$ & $\begin{array}{c}\text { Foreign } \\
\text { taste }\end{array}$ & $\begin{array}{l}\text { Overall } \\
\text { quality }\end{array}$ \\
\hline \multirow{4}{*}{ Light-red } & Control fruit & $6.38 \mathrm{c}$ & $4.49 \mathrm{ab}$ & $3.99 \mathrm{~cd}$ & $0.65 \mathrm{a}$ & $0.60 \mathrm{a}$ & $7.12 \mathrm{~d}$ \\
\hline & Untreated & $5.30 \mathrm{~b}$ & $3.20 \mathrm{a}$ & $3.45 \mathrm{bc}$ & $0.24 \mathrm{a}$ & $0.71 \mathrm{a}$ & $4.75 b$ \\
\hline & 1-MCP treated & $5.25 \mathrm{~b}$ & $4.58 \mathrm{~b}$ & $3.12 \mathrm{ab}$ & $0.30 \mathrm{a}$ & $0.30 \mathrm{a}$ & $4.98 \mathrm{~b}$ \\
\hline & Means & $5.64 \mathrm{~A}$ & $4.09 \mathrm{~A}$ & $3.52 \mathrm{~A}$ & $0.40 \mathrm{~A}$ & $0.54 \mathrm{~A}$ & $5.62 \mathrm{~A}$ \\
\hline \multirow{4}{*}{ Pink } & Control fruit & $5.72 b$ & $3.27 \mathrm{a}$ & $4.36 \mathrm{~d}$ & $0.33 \mathrm{a}$ & $0.01 \mathrm{a}$ & $6.05 c$ \\
\hline & Untreated & $4.23 \mathrm{a}$ & $3.94 \mathrm{a}$ & $3.28 \mathrm{ab}$ & $0.34 \mathrm{a}$ & $0.22 \mathrm{a}$ & $3.95 \mathrm{a}$ \\
\hline & 1-MCP treated & $4.31 \mathrm{a}$ & $4.82 \mathrm{~b}$ & $2.79 \mathrm{a}$ & $0.23 \mathrm{a}$ & $0.31 \mathrm{a}$ & $4.48 \mathrm{ab}$ \\
\hline & Means & $4.76 \mathrm{~A}$ & $4.01 \mathrm{~A}$ & $3.48 \mathrm{~A}$ & $0.30 \mathrm{~A}$ & $0.18 \mathrm{~A}$ & $4.83 \mathrm{~A}$ \\
\hline
\end{tabular}


34

Overall quality descriptor shows how experts perceive, in general, the fruit quality and therefore it summarizes the individual sensory impressions. It can be seen that the scores for overall quality are highly differentiated, for 4-week storage especially (Tab. 4 and Tab. 5). In the case of the fruits stored for 3 weeks, the quality of the fruits harvested in light-red stage was rated on similar level for 1-MCP treated, untreated and control fruits, but in the case of fruits harvested in pink maturity stage, the stored fruits, whether treated or untreated, were rated lower than the control ones. After 4 weeks of storage the differences between stored and control fruits became even bigger, and the 1-MCP treated fruits showed a tendency to higher scores than the untreated ones.

Semi-consumer hedonic test of tomatoes liking gives the information how the fruits are perceived by the expert panel from a consumer's point of view. The performed test was not a strict full consumer test, since the panel was small and not representative for a broad spectrum of consumers, but obtained information, even if it is limited, is quite useful. Hedonic scores for tomatoes liking after 3 weeks of storage were slightly differentiated, and the lowest scores got 1 MCP treated pink fruits (Tab. 6). However, in the case of fruits harvested in light-red stage a tendency to higher scores for the 1-MCP treated ones is evident. When we look at the results after 4-week storage, a positive effect of the treatment is evident, for the pink fruits especially, where the difference between the treated and untreated fruits is statistically significant.

Tab. 6. Scores for consumer liking for 'cherry' tomato fruits after storage (scale 0-10)

\begin{tabular}{|c|c|c|c|}
\hline \multirow{2}{*}{$\begin{array}{c}\text { Maturity } \\
\text { stage at } \\
\text { harvest }\end{array}$} & \multirow[b]{2}{*}{ Treatment } & \multicolumn{2}{|c|}{ Consumer liking } \\
\hline & & $\begin{array}{l}\text { 3-week } \\
\text { storage }\end{array}$ & $\begin{array}{l}\text { 4-week } \\
\text { storage }\end{array}$ \\
\hline \multirow{4}{*}{ Light-red } & Control fruit & $7.82 \mathrm{c}$ & $6.82 c$ \\
\hline & Untreated & $6.94 b$ & $4.15 b$ \\
\hline & 1-MCP treated & $7.63 \mathrm{bc}$ & $4.49 \mathrm{~b}$ \\
\hline & Mean & $7.46 \mathrm{~B}$ & $5.15 \mathrm{~A}$ \\
\hline \multirow{4}{*}{ Pink } & Control fruit & $7.13 \mathrm{~b}$ & $6.73 c$ \\
\hline & Untreated & $6.60 \mathrm{ab}$ & $3.24 \mathrm{a}$ \\
\hline & 1-MCP treated & $6.14 \mathrm{a}$ & $4.63 \mathrm{~b}$ \\
\hline & Mean & $6.62 \mathrm{~A}$ & $4.87 \mathrm{~A}$ \\
\hline
\end{tabular}

The results described above show that 1-MCP treatment influences some of sensory quality traits, but the effect is differentiated and depends on maturity stage of the fruits at harvest and also on storage duration. What is also important, the treatment does not cause noticeable increase of intensity of the most negatively perceived quality attributes - foreign odour and taste, bitter taste, and foreign taste. Moreover, overall quality impression for the 1-MCP treated fruits after storage period is high enough, compared to the untreated ones, therefore the treated stored fruits can compete with the freshly harvested ripe fruits on food market.

The results obtained in our study do not confirm fully Cliff et al. (2009) report. These authors pointed out that 1MCP treatment could negatively influence sensory characteristics of tomato fruits. However, tomato cultivars used by the authors were different from traditional big fruits.
Tab. 7. Correlation coefficients for sensory quality evaluation of 'cherry' tomatoes

\begin{tabular}{cccccc}
\hline \multirow{2}{*}{$\begin{array}{c}\text { Scores } \\
\text { for }\end{array}$} & $\begin{array}{c}\text { 'Tomato' } \\
\text { flavour }\end{array}$ & $\begin{array}{c}\text { Sour } \\
\text { taste }\end{array}$ & $\begin{array}{c}\text { Sweet } \\
\text { taste }\end{array}$ & $\begin{array}{c}\text { Flesh } \\
\text { firm- } \\
\text { ness }\end{array}$ & $\begin{array}{c}\text { Flesh } \\
\text { juici- } \\
\text { ness }\end{array}$ \\
\hline $\begin{array}{c}\text { Overall } \\
\text { quality } \\
\text { impression }\end{array}$ & $0.79^{* *}$ & 0.20 & 0.20 & $0.55^{*}$ & $0.60^{*}$ \\
$\begin{array}{c}\text { Consumer's } \\
\text { liking for } \\
\text { tomatoes }\end{array}$ & $0.72^{*}$ & -0.15 & $0.45^{\circ}$ & $0.53^{*}$ & $0.48^{\circ}$ \\
\hline
\end{tabular}

Explanation: ${ }^{\circ}$ - correlation significant at $\mathrm{p}<0.10$, ${ }^{*}$ correlation significant at $\mathrm{p}<0.05,{ }^{* *}$ correlation significant at $\mathrm{p}<0.01$

In Tab. 7 correlation coefficients between some sensory attributes and scores for overall quality and for consumer liking are shown. It can be seen that overall quality impression is significantly correlated with characteristic tomato taste intensity, as well as with flesh firmness and flesh juiciness. However, the correlation between overall quality and sour taste or with sweet taste was weak. The same sensory attributes were important in hedonic evaluation of liking in semi-consumer test.

\section{Conclusions}

The study showed that 1-MCP treatment of 'cherry' tomatoes affects some sensory quality descriptors of the stored fruits compared with the untreated ones. The influence of the treatment is mostly positive and reflects increased storability of the treated fruits. It can be also concluded that 1-MCP treatment of 'cherry' tomatoes does not negatively influences overall sensory quality impression for the fruits stored for 3 weeks, compared with freshly harvested ripe fruits, and compared with the stored untreated fruits results in a higher overall quality. However, when the storage period is prolonged up to 4 weeks, quality of stored fruits, even 1-MCP treated ones, shows significant degradation in respect of most sensory attributes in comparison with the stored ones. Also, consumer liking for the stored fruits is rated lower in that case, mainly due to decrease of flavour characteristic to tomatoes.

\section{Acknowledgements:} 728640 .

The study was supported by NCN, grant N N310

\section{References}

Anonymous (1996). Sensory analysis. Experts. PN-ISO 8586-2. Anonymous (1999). Sensory analysis. Methodology. PN-ISO 6564.

Azodanlou R, Darbellayb C, Luisierc J-L, Villettazc J-C, Amadoa $R$ (2003). Development of a model for quality assessment of tomatoes and apricots. Lebensm-Wiss Technol 36:223-233.

Beno-Moualem D, Gusev L, Dvir O, Pesis E, Meir S, Lichter A (2004). The effects of ethylene, methyl jasmonate and 1-MCP on abscission of cherry tomatoes from the bunch and expression of endo-1,4-glucanases. Plant Sci 167:499-507. 
Blankenship SM, Dole JM (2003). 1-Methylcyclopropene: a review. Postharvest Biol Tec 28:1-25.

Cliff M, Lok S, Changwen Lu, Toivonen PMA (2009). Effect of 1-methylcyclopropene on the sensory, visual, and analytical quality of greenhouse tomatoes. Postharvest Biol Tec 53:1115.

Ergun M, Sargent SA, Huber DJ (2006). Postharvest quality of grape tomatoes treated with 1-methylcyclopropene at advanced ripeness stages. HortScience 41(1):183-187.

Fan X, Mattheis JP (2000). Yellowing of broccoli in storage is reduced by 1-methylcyclopropene. HortScience 35:885-887.

Gajewski M (2000). Storability of tomato (Lycopersicon esculentum Mill.) glasshouse cultivars from field growing with supports. Annales Universitas Mariae Curie-Skłodowska, Lublin, Supl. 8:311-317 [in Polish with English summary].

Gajewski M, Arasimowicz D (2004). Sensory quality of eggplant fruits (Solanum melongena L.) as affected by cultivar and maturity stage. Polish Journal of Food and Nutrition Sciences 13/54 (3):249-254.

Getinet H, Seyoum T, Woldetsadik K (2008). The effect of cultivar, maturity stage and storage environment on quality of tomatoes. J Food Eng 87:467-478.

Guillén F, Castillo S, Zapata PJ , Martinez-Romero D, Serrano M, Valero D (2007). Efficacy of 1-MCP treatment in tomato fruit. 1. Duration and concentration of 1-MCP treatment to gain an effective delay of postharvest ripening. Postharvest Biol Tec 43:23-27.

Guillén F, Castillo S, Zapata PJ, Martínez-Romero D, Valero D, Serrano M (2006). Efficacy of 1-MCP treatment in tomato fruit. Effect of cultivar and ripening stage at harvest. Postharvest Biol Tec 42:235-242.

Huber DJ (2008). Suppression of ethylene responses through application of 1-methylcyclopropene: a powerful tool for elucidation ripening and senescence mechanisms in climacteric and nonclimacteric fruits and vegetables. HortScience 43:106-111.

Mazur KZ, Gajewski M, Czechowska E, Decyk J, Metera A M, Marcinkowska MM, Wtulich JA, Przybył JL (2013). Effect of 1-MCP Treatment on Quality of Stored 'Cherry' Tomatoes. CAMA IX International Controlled and Modified Atmosphere Research Conference, Trani, Italy, 3-7 June 2013:52.

Meilgaard M, Civille GV, Carr BT (1999). Sensory Evaluation Techniques. $3^{\text {rd }}$ ed., CRC Press, Boca Raton, London.
Mir N, Canoles M, Beadury R (2004). Inhibiting Tomato Ripening with 1-Methylcyclopropene. J Amer Soc Hort Sci 129(1):112-120.

Moretti CL, Araújo AL., Marouelli WA, Silva WC. (2002). 1Methylcyclopropene delays tomato fruit ripening. Hortic Bras 20(4):659-663.

Mostofi Y, Toivonen PMA, Lessani H, Babalar M, Lu CW (2003). Effects of 1-methylcyclopropene on ripening of greenhouse tomatoes at three storage temperatures. Postharvest Biol Tec 27:285-292.

Opiyo AM, Ying TJ (2005). The effects of 1-methylcyclopropene treatment on the shelf life and quality of cherry tomato (Lycopersicon esculentum var. cerasiforme) fruit. Int J Food Sci Tech 40:665-673.

Roberts PK, Sargent SA, Fox AJ (2002). Effect of storage temperature on ripening and postharvest quality of grape and mini-pear tomatoes. Proc Fla State Hort Soc 115:80-84.

Sayed A, Nakano K, Maezawa S (2004). Combined effect of heat treatment and modified atmosphere packaging on the color development of cherry tomato. Postharvest Biol Tec 34:113116.

Suslow TV, Cantwell M (2009). Tomato. Recommendation for maintaining postharvest quality. www.postharvest.ucdavis/producefacts/veg/tomato.

Tadesse TN, Farneti B, Woltering E (2012). Effect of Ethylene and 1-Methylcyclopropene on Color and Firmness of Red and Breaker Stage Tomato stored at Different Temperatures. American Journal of Food Technology 7(9):542-551.

Tassoni A, Watkins CB, Davies PJ (2006). The effect of 1-MCP treatment on ripening in tomato fruit: changes in ethylene, polyamines and associated gene expression. J Exp Bot 57:3313-3325.

Toor RK, Savage GP (2006). Changes in major antioxidant components of tomatoes during post-harvest storage. Food Chem 99:724-727.

Vijay P, Rakesh P, Girish CS (2010) Ripening of tomato (Solanum lycopersicum L.). Part I: 1-methylcyclopropene mediated delay at higher storage temperature. J Food Sci Technol 47(5):519-526.

Watkins CB (2006). The use of 1-methylcyclopropene (1-MCP) on fruits and vegetables. Biotechnology Advances 24:389-409.

Wills RBH, Ku VVV (2002). Use of 1-MCP to extend the time to ripen of green tomatoes and postharvest life of ripe tomatoes. Postharvest Biol Tec 26:85-90. 